\title{
1,25-Vitamin $D_{3}$ Deficiency Induces Albuminuria
}

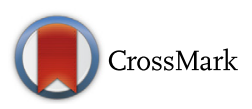

Ramon Sonneveld, ${ }^{* \dagger}$ Joost G.J. Hoenderop, ${ }^{\dagger}$ Andrea W.D. Stavenuiter, ${ }^{\ddagger}$ Evelina Ferrantelli, ${ }^{\ddagger}$

Marijke P.A. Baltissen, ${ }^{*}$ Henry B. Dijkman, ${ }^{\S}$ Sandrine Florquin, ${ }^{\S}$ Angelique L. Rops, ${ }^{*}$ Jack F.M. Wetzels, ${ }^{*}$ Jo H.M. Berden, ${ }^{*}$ Johan van der Vlag, * and Tom Nijenhuis*

From the Departments of Nephrology, ${ }^{*}$ Physiology, ${ }^{\dagger}$ and Pathology, ${ }^{\S}$ Radboud University Medical Center, Nijmegen; and the Department of Cell Biology and Immunology, ${ }^{\ddagger}$ VU Medical Center, Amsterdam, the Netherlands

Accepted for publication November 19, 2015.

Address correspondence to Tom Nijenhuis, M.D., Ph.D., Department of Nephrology, 464, Radboud University Medical Center, PO Box 9101, 6500 HB Nijmegen, the Netherlands. E-mail: tom.nijenhuis@ radboudumc.nl.

\begin{abstract}
Vitamin D plays an important role in renal (patho)physiology. Patients with glomerular diseases have an injured renal filtration barrier, leading to proteinuria and reduced renal function. An impaired renal function also leads to 1,25 -vitamin $D_{3}$ deficiency as a result of reduced renal $1 \alpha$-hydroxylase activity. Vitamin $D$ treatment to reduce proteinuria remains controversial, although there is an inverse correlation between vitamin $D$ levels and proteinuria. Herein, we showed that 1,25-vitamin $D_{3}-$ deficient 25-hydroxy-vitamin- $D_{3}$ $1 \alpha$-hydroxylase knockout mice and 1,25-vitamin $D_{3}$-deficient rats develop podocyte injury and renal dysfunction. Glomerular injury was characterized by proteinuria and partial podocyte foot process effacement. Expression of nephrin, podocin, desmin, and transient receptor potential channel 66 in the podocyte was significantly altered in 1,25-vitamin $D_{3}$-deficient animals. Supplementation with 1,25 -vitamin $D_{3}$ or 1,25-vitamin $D_{2}$ prevented podocyte effacement or reversed glomerular and tubulointerstitial damage in 1,25 -vitamin $D_{3}$-deficient animals, thereby preserving and restoring renal function, respectively. The effect of 1,25-vitamin $D_{3}$ deficiency and 1,25-vitamin $D_{3}$ and 1,25-vitamin $D_{2}$ repletion on proteinuria could not be explained by hypocalcemia, changes in parathyroid hormone, or fibroblast growth factor 23 . This study demonstrates that 1,25 -vitamin $D_{3}$ deficiency directly leads to renal injury in rodents. Translated to human subjects, this would underline the need for early vitamin $D$ supplementation in patients with glomerular disease and chronic renal insufficiency, which might inhibit or potentially reverse renal injury. (Am J Pathol 2016, 186: 794-804; http://dx.doi.org/10.1016/j.ajpath.2015.11.015)
\end{abstract}

Vitamin D is a steroid hormone with important physiological roles in several organs and tissues. ${ }^{1} 1,25$-Vitamin $\mathrm{D}_{3}\left(1,25-\mathrm{D}_{3}\right)$ is the active form of vitamin $\mathrm{D}$, and known for its role in calcium and phosphate homeostasis. However, the pluripotent $1,25-$ vitamin $\mathrm{D}_{3}$ also influences processes in growth and development, ${ }^{2,3}$ cardiovascular disease, ${ }^{4,5}$ cancer, ${ }^{6,7}$ and the immune system. ${ }^{8}$ Treatment with vitamin $\mathrm{D}$ analogs seems to delay renal function decline and reduce proteinuria in animals and patients with chronic kidney disease. ${ }^{9-11}$ However, the therapeutic effect of vitamin D remains heavily debated. ${ }^{12}$ Interestingly, scarce literature data describe an association between low serum vitamin D levels and morbidity, mortality, and renal damage as well as increased albuminuria. ${ }^{4,13-15}$ These studies do not prove causality, and the exact molecular mechanisms by which vitamin $\mathrm{D}$ deficiency would cause these effects are unknown.

Podocytes and the interconnecting slit diaphragm in the glomerular filtration barrier are injured in glomerular diseases, such as focal segmental glomerular sclerosis (FSGS) and diabetic nephropathy, leading to renal dysfunction and proteinuria. ${ }^{16-19}$ Persisting renal injury can lead to chronic kidney disease and end-stage renal disease. In renal insufficiency, renal proximal tubular cells show reduced $1 \alpha$-hydroxylation capacity, resulting in $1,25-\mathrm{D}_{3}$ deficiency. ${ }^{20}$ Patients with chronic kidney disease are treated with vitamin D analogs, but often only after secondary hyperparathyroidism has developed, with the goal to correct the disturbed calcium-phosphorus homeostasis. We

\footnotetext{
Supported by a Dutch Diabetes Fund Ruby Diabetes Research grant 2009.80.118, a Genzyme Renal Innovations Program grant, Dutch Kidney Foundation Kolff Career Stimulation grants KJPB 07.0001 and 13OKS023 (T.N.), Dutch Kidney Foundation grant C09.2331 (A.W.D.S.), Marie Curie grant ITN287813, EuTRiPD 2011 (E.F.), Dutch Organization for Scientific Research grant NWO-ALW 818.02.001 (J.G.J.H.), a European Young Investigator award (J.G.J.H.), and a Netherlands Organisation for Scientific Research Vici grant 016.130.668 (J.G.J.H.).
}

Disclosures: AbbVie (Chicago, IL) provided paricalcitol (Zemplar). 
Table 1 Primary Antibodies Used for Immunofluorescence Staining

\begin{tabular}{lllll}
\hline Antigen & Antibody & Description & Dilution & Manufacturer \\
\hline TRPC6 & ACC-017 & Rabbit-anti-mouse & $1: 1600$ & Alomone (Jerusalem, Israel) \\
TRPC6 & AB62999 & Rabbit-anti-rat & $1: 500$ & Abcam (Cambridge, UK) \\
Desmin & SC-7559 & Goat-anti-mouse & $1: 200$ & Santa Cruz (Santa Cruz, CA) \\
Nephrin & AF-3159 & Goat-anti-mouse & $1: 200$ & R\&D (Minneapolis, MN) \\
Podocin & SC-22298 & Goat-anti-mouse & $1: 50$ & Santa Cruz \\
Caspase 3 & $9661-S$ & Rabbit-anti-mouse & $1: 200$ & Cell Signaling Technology (Boston, MA) \\
Granulocytes & LY-6G & Rat-anti-mouse & $1: 100$ & eBioscience, Inc. (San Diego, CA) \\
NGAL & & Rat-anti-mouse & $1: 50$ & R\&D \\
Synaptopodin & 65194 & Mouse-anti-rat & $1: 5$ & Progen Pharmaceuticals Ltd (Toowong, QLD, Australia) \\
IgG & A11001 & Goat-anti-mouse & $1: 200$ & Invitrogen (Carlsbad, CA) \\
IgM & A21044 & Goat-anti-mouse & $1: 200$ & Life Technologies (Carlsbad, CA) \\
IgA & 556978 & Rat-anti-mouse & $1: 100$ & BD Pharmingen (San Diego, CA) \\
C3 & 14631 & Goat-anti-mouse & $1: 40$ & Nordic (Tilburg, the Netherlands) \\
CD4 & 550278 & Rat-anti-mouse & $1: 50$ & BD Pharmingen \\
CD8 & 550281 & Rat-anti-mouse & $1: 50$ & BD Pharmingen \\
CD68 & MCA1957 & Rat-anti-mouse & $1: 1600$ & AbD (Serotec, UK) \\
\hline
\end{tabular}

NGAL, neutrophil gelatinase-associated lipocalin; TRPC6, transient receptor potential channel 6 .

suggest that vitamin D deficiency itself induces or aggravates glomerular injury. Podocytes express the vitamin D receptor (VDR), and undergo ultrastructural changes when exposed to vitamin D. ${ }^{21,22}$ Vitamin D is known to regulate vital proteins in the slit diaphragm, such as nephrin and podocin, and we recently demonstrated the direct regulation of the transient receptor potential channel C6 (TRPC6) by vitamin D. ${ }^{23-27}$ Thus, in addition to being a consequence of renal insufficiency, we hypothesize that $1,25-\mathrm{D}_{3}$ deficiency itself can also cause renal injury.

In our study on regulation of TRPC6 by vitamin D, we demonstrated a previously unreported proteinuria in 1,25- $\mathrm{D}_{3}-$ deficient 25 -hydroxy-vitamin- $\mathrm{D}_{3}-1 \alpha$-hydroxylase knockout mice (CYP27B1 or $1 \alpha-\mathrm{OHase} \mathrm{KO}) .{ }^{26}$ Herein, we assessed the renal phenotype of these animals by studying in detail the effects of this inherited $1,25-\mathrm{D}_{3}$ deficiency on the glomerulus, in particular the podocyte, and the tubulointerstitium. In addition, we studied glomerular, tubular, and podocyte injury in rats with acquired $1,25-\mathrm{D}_{3}$ deficiency. Furthermore, we excluded that the effects of $1,25-\mathrm{D}_{3}$ deficiency were secondary to the hypocalcemia or altered hormonal regulation of calcium-phosphorus balance in this situation. Elucidating the renal phenotype of these $1,25-\mathrm{D}_{3}-$ deficient animal models provides new insights into the complex relationship between renal injury and $1,25-\mathrm{D}_{3}$ deficiency, and increases our understanding of the pluripotent effects of vitamin D.

\section{Materials and Methods}

\section{Animal Studies}

All animal procedures were approved by the Animal Ethics Committee of the Radboud University (Nijmegen, the Netherlands) or the VU Medical Center (Amsterdam, the Netherlands), in accordance with the guidelines of the Dutch Council for Animal Care and the European Communities Council Directive (86/609/EEC).
1 $\alpha$-OHase $(C Y P 27 B 1)$ KO mice with a C57BL/6 background were generated as previously described. ${ }^{27}$ From an age of 5 weeks, mice received either a $2.0 \%$ calcium diet, as performed previously, ${ }^{28}$ or daily i.p. injections with $1000 \mathrm{pg} / \mathrm{g}$ body weight $1,25-\mathrm{D}_{2}, 500$ (high dose) or 25 (low dose) pg/g body weight $1,25-\mathrm{D}_{3}$ (Sigma-Aldrich, St. Louis, MO), or vehicle for 6 weeks ( $n=8$ per group). These animals and untreated 5-week-old wild-type (WT) and KO mice were housed in metabolic cages for 24 hours to collect urine samples. Subsequently, animals were sacrificed and kidneys and blood were sampled for analysis.

Wistar rats (Charles River WU, Sulzfeld, Germany), weighing 275 to $300 \mathrm{~g}$ at the start of the experiment, were injected with $32 \mathrm{ng} 1,25-\mathrm{D}_{2}$ at days $0,2,4,7,9$, and 11 to deplete the endogenous pool of vitamin $\mathrm{D}_{3}$. In addition, rats received a vitamin $\mathrm{D}$ deficient, but high calcium and phosphorus, diet (TD.120503 Brown C.C. Vitamin D Deficient Diet with Lactose; Harlan Laboratories, Inc. Madison, WI). From day 21 , the animals were orally treated three times weekly with vehicle, $100 \mathrm{ng} / \mathrm{kg} 1,25-\mathrm{D}_{2}$, or $30 \mathrm{ng} / \mathrm{kg} 1,25-\mathrm{D}_{3}$, as described before ( $n=8$ animals per group). ${ }^{29}$ The choice of particularly these two vitamin $D$ analogs was on the basis of our in vitro experimental data (described in Results). After 8 weeks of treatment, rats were sacrificed, and urine, blood, and kidneys were harvested.

\section{Serum and Urine Chemistry}

Urinary neutrophil gelatinase-associated lipocalin (NGAL; $\mathrm{R} \& \mathrm{D}$, Minneapolis, MN) and IgG (Roche, Basel, Switzerland for mouse; Antibodies-online, Aachen, Germany for rat) levels and serum fibroblast growth factor $23 \mathrm{C}$-terminal (Immunotopics, San Clemente, CA) and parathyroid hormone (PTH) 1-84 (Immunotopics) concentrations were measured in enzyme-linked immunosorbent assays. All enzyme-linked immunosorbent assays were performed according to the manufacturer's protocol. Calcium, albumin, urea, and 

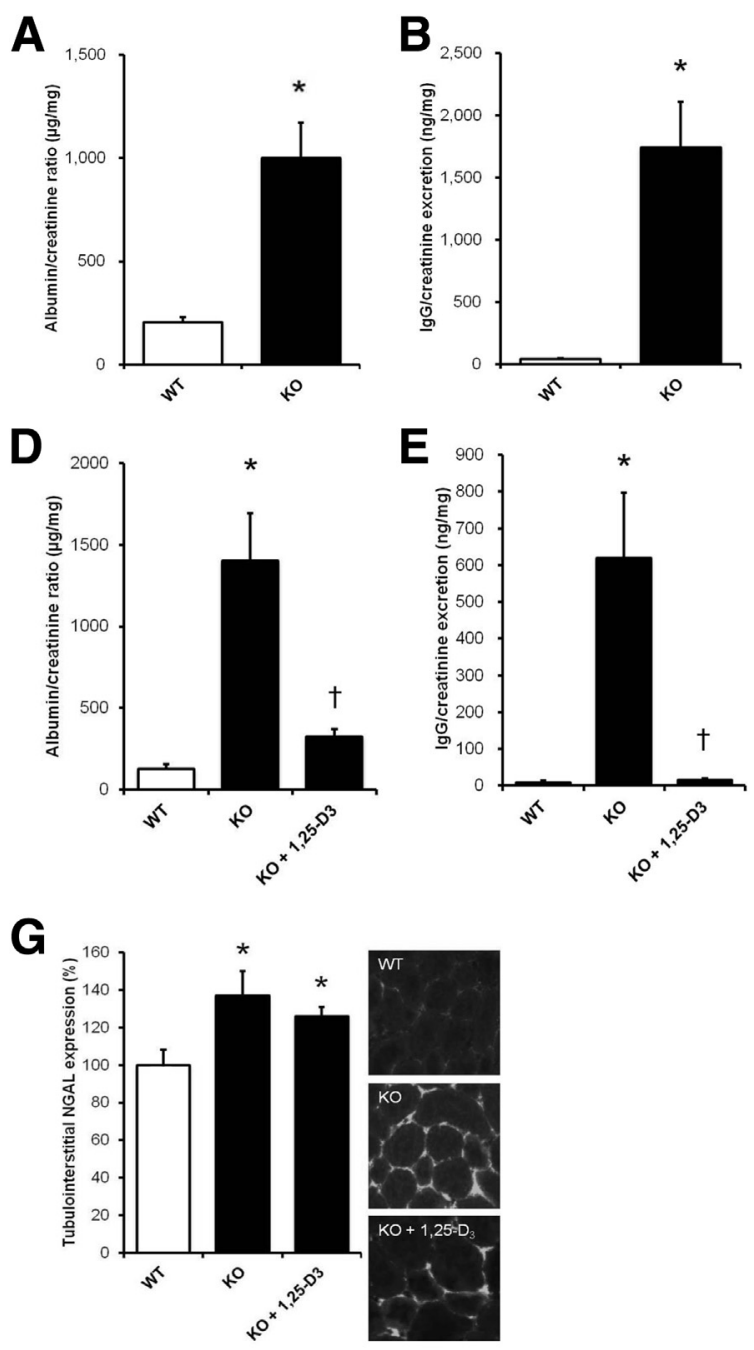

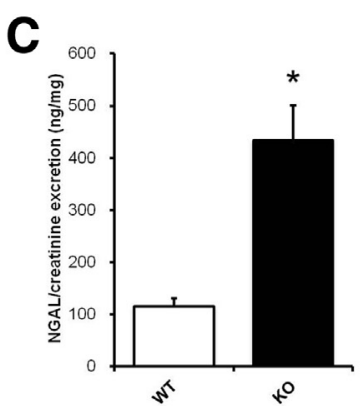

$\mathbf{F}$
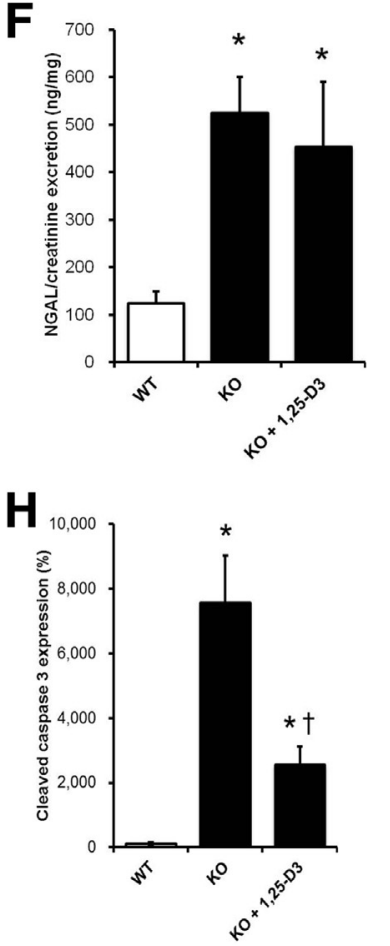

Figure 1 Renal injury in 25-hydroxy-vitamin$D_{3}-1 \alpha$-hydroxylase knockout ( $1 \alpha-\mathrm{OH}$ ase $\left.\mathrm{K} 0\right)$ mice. Renal injury was assessed by urinary albumin/ creatinine ratio (A), IgG/creatinine ratio (B), and neutrophil gelatinase-associated lipocalin (NGAL)/ creatinine ratio excretion (C) in 4-week-old $1 \alpha$ $\mathrm{OHase} \mathrm{KO}$ and wild-type (WT) mice. Five-week-old $1 \alpha-0$ Hase $\mathrm{KO}$ mice were given daily injections with a low-dose $(25 \mathrm{pg} / \mathrm{g})$ calcitriol $\left(1,25-\mathrm{D}_{3}\right)$ or vehicle for 6 weeks, after which mice were sacrificed. Glomerular and interstitial injury was assessed by urinary albumin/creatinine ratio (D), $\mathrm{IgG} /$ creatinine ratio $(\mathrm{E})$, and $\mathrm{NGAL} /$ creatinine ratio excretion (F). Tubulointerstitial NGAL protein (G) and cleaved caspase $3(\mathbf{H})$ expression. Protein and mRNA expression are depicted as percentage of vehicle-treated WT mice. Statistical tests used were $t$-test $(\mathbf{A}-\mathbf{C})$ and analysis of variance with Bonferroni post hoc analysis (D-H). ${ }^{*} P<0.05$ versus $W T ;{ }^{\dagger} P<0.05$ versus $\mathrm{K} 0 . N=8$ mice per group $(\mathbf{A}-\mathbf{H})$. Original magnification, $\times 400(\mathbf{G})$. KO, knockout. phosphate were determined on an Architect C16000 Clinical Chemistry Analyzer (Abbott Diagnostics, Chicago, IL). Serum vitamin D levels were assessed by radioimmunoassay after immunoextraction (IDS, Tyne and Wear, UK).

\section{Transmission EM}

Immersion fixation was used for electron microscopy (EM). Kidney cortex was fixed in $2.5 \% \mathrm{v} / \mathrm{v}$ glutaraldehyde dissolved

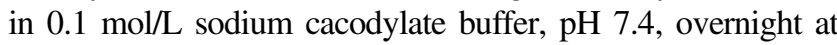
$4^{\circ} \mathrm{C}$. The tissue was post-fixed in palade-buffered $2 \% \mathrm{w} / \mathrm{v}$ $\mathrm{OsO}_{4}$, dehydrated, and embedded in Epon812, Luft's procedure (Merck, Darmstadt, Germany). Ultrathin sections were contrasted with $4 \% \mathrm{w} / \mathrm{v}$ uranyl acetate and subsequently with lead citrate. Podocyte effacement was analyzed using a Jeol 1200 EX2 electron microscope (JEOL, Tokyo, Japan).

\section{Immunohistochemistry}

Frozen kidney cortex of five to eight animals per group was cut into cryosections ( $2 \mu \mathrm{m}$ thick) and stained for several proteins (Table 1). Alexa-conjugated secondary antibodies were used for detection, and sections were embedded in Vectashield (Vector Labs, Burlingame, CA). The antibody against granulocytes was directly labeled and, therefore, no secondary antibody was used. Analysis was performed on 30 glomeruli per animal by determining the fluorescent intensity and surface area using ImageJ software version 1.49i (NIH, Bethesda, MD). For the caspase-3 staining, we counted the amount of positive cells per microscopic field. We used a standard periodic acid-Schiff staining on paraffin sections to study glomerular and tubulointerstitial morphology by light microscopy.

\section{Cell Culture Studies}

Conditionally immortalized mouse podocytes (MPC-5) cells were cultured as described previously. ${ }^{30}$ After 2 weeks of differentiation, cells were treated with 0.25 $\mu \mathrm{g} / \mathrm{mL}$ doxorubicin (Adriamycin) in combination with vehicle or a vitamin $\mathrm{D}$ analog [cholecalciferol $\left(\mathrm{D}_{3}\right)$, calcidiol $\left(25-\mathrm{D}_{3}\right), \alpha$-calcidiol $\left(1 \alpha-\mathrm{D}_{3}\right)$, calcitriol $\left(1,25-\mathrm{D}_{3}\right)$, ergocalciferol $\left(\mathrm{D}_{2}\right)$, doxercalciferol $\left(1 \alpha-\mathrm{D}_{2}\right)$, or paricalcitol 
Table 2 Clinical Parameters of Wild-Type and $1 \alpha-0$ Hase KO Mice Treated with Vehicle or $1,25-D_{3}$

\begin{tabular}{|c|c|c|c|}
\hline Parameters & WT & KO & $\mathrm{K} 0+$ Vitamin $\mathrm{D}$ \\
\hline Serum PTH $(\mathrm{pg} / \mathrm{mL})$ & $315 \pm 68$ & $1907 \pm 353^{*}$ & $1540 \pm 174^{*}$ \\
\hline PTH receptor expression (\% vs WT) & $100 \pm 12.1$ & $81.5 \pm 5.6$ & $89.0 \pm 28.0$ \\
\hline VDR expression (\% vs WT) & $100 \pm 12.5$ & $27.0 \pm 4.6^{*}$ & $10.4 \pm 2.8^{* \dagger}$ \\
\hline Serum FGF23 (pg/mL) & $225 \pm 66$ & ND & ND \\
\hline \multirow[t]{2}{*}{ Body weight (g) } & $23.4 \pm 1.7 \mathrm{M}$ & $17.4 \pm 0.6 M^{*}$ & $19.0 \pm 1.3 \mathrm{M}$ \\
\hline & $18.5 \pm 0.8 \mathrm{~F}$ & $13.9 \pm 0.7 \mathrm{~F}^{*}$ & $14.3 \pm 0.2 \mathrm{~F}$ \\
\hline Serum phosphate (mmol/L) & $2.58 \pm 0.09$ & $2.02 \pm 0.08$ & $2.27 \pm 0.05^{* \dagger}$ \\
\hline Serum albumin $(\mathrm{g} / \mathrm{L})$ & $16.2 \pm 0.7$ & $17.4 \pm 0.6$ & $17.5 \pm 0.6$ \\
\hline 24-h albumin excretion (mg) & $0.01 \pm 0.00$ & $0.32 \pm 0.09 *$ & $0.07 \pm 0.04^{\dagger}$ \\
\hline Blood urea nitrogen $(\mathrm{mg} / \mathrm{dL})$ & $30.1 \pm 5.0$ & $29.1 \pm 1.8$ & $29.8 \pm 3.4$ \\
\hline
\end{tabular}

Five-week-old $1 \alpha-0$ Hase $\mathrm{K} 0$ mice were given daily i.p. injections with $1,25-\mathrm{D}_{3}$ or vehicle for 6 weeks. The weight of the mice was determined, and blood and urine samples were analyzed. Data are given as means \pm SD.

$* P<0.05$ vs WT.

${ }^{\dagger} P<0.05$ vs KO.

F, female; M, male; FGF, fibroblast growth factor; K0, knockout; ND, not detectable; PTH, parathyroid hormone; VDR, vitamin D receptor; WT, wild type; $1 \alpha$-0Hase, 25 -hydroxy-vitamin- $D_{3}-1 \alpha$-hydroxylase; $1,25-D_{3}$, calcitriol.

$\left.\left(1,25-\mathrm{D}_{2}\right)\right]$ at a concentration of 0.1 or $1 \mu \mathrm{mol} / \mathrm{L}$. After 24 hours, cells were harvested.

The TRPC6 promoter activity assay was performed as described previously. ${ }^{26}$ Briefly, after transfection, cells were treated with vehicle or a vitamin $\mathrm{D}$ analog $\left(\mathrm{D}_{3}, 25-\mathrm{D}_{3}\right.$, $1 \alpha-D_{3}, 1,25-D_{3}, D_{2}, 1 \alpha-D_{2}$, or $\left.1,25-D_{2}\right)$ at a concentration of 0.1 or $1 \mu \mathrm{mol} / \mathrm{L}$. After 24 hours, cells were harvested and a luciferase reporter assay (Promega, Madison, WI) was performed.

\section{Real-Time Quantitative PCR Analysis}

RNA was isolated from kidney cortex or cultured MPC-5 cells. cDNA synthesis and real-time quantitative PCR was performed as described previously. ${ }^{31}$

\section{Statistical Analysis}

Results in the text and figures are depicted as means \pm SEM. The appropriate test was used to determine significance with SPSS software version 13 (IBM, New York, NY), as described in the figure legends. $P<0.05$ was considered significant.

\section{Results}

Inherited $1,25-D_{3}$ Deficiency Induces Glomerular and Tubulointerstitial Injury and Proteinuria

A significant proteinuria, determined as albumin/creatinine ratio and total 24-hour urine albumin excretion, was detected in 4-week-old $1 \alpha$-OHase $\mathrm{KO}$ mice (Figure $1 \mathrm{~A}$ and Table 2), with increased urinary IgG excretion suggesting a glomerular origin (Figure 1B). Urinary NGAL excretion, a measure of tubular damage, was also increased in the $\mathrm{KO}$ mice (Figure 1C). Treating $\mathrm{KO}$ animals from week 5 onward with a low dose $(25 \mathrm{pg} / \mathrm{g})$ of $1,25-\mathrm{D}_{3}$ for 6 weeks normalized the urinary albumin/creatinine ratio (Figure 1D) and total 24-hour albumin excretion (Table 2), and reduced urinary IgG (Figure 1E) excretion to WT levels, without affecting NGAL excretion (Figure 1F). Immunohistochemistry demonstrated increased tubular NGAL expression in the KO mice, which remained unchanged by supplementation with 1,25- $\mathrm{D}_{3}$ (Figure 1G). Tubulointerstitial staining for cleaved caspase- 3 was increased in $\mathrm{KO}$ mice, and was reduced, but not normalized, by $1,25-\mathrm{D}_{3}$ (Figure $1 \mathrm{H}$ ).

\section{Podocyte Injury in Inherited $1,25-D_{3}$ Deficiency}

Periodic acid-Schiff staining showed no visible abnormalities in the glomerulus, tubuli, or tubulointerstitium of 4- or 11 -week-old $1 \alpha$-OHase KO mice (results not shown). EM analysis detected no podocyte foot process effacement in the 4-week-old KO mice (results not shown). However, glomerular desmin and TRPC6, as measures of podocyte injury, were increased in the KOs when compared with WT animals (Figure 2, A and B). Moreover, nephrin expression was down-regulated in the $\mathrm{KO}$ mice (Figure 2C). To determine the progression and reversibility of podocyte injury, we also examined $\mathrm{KO}$ mice treated with a low dose $\left(25 \mathrm{pg} / \mathrm{g}\right.$ ) of $1,25-\mathrm{D}_{3}$ for 6 weeks. EM revealed partial foot process effacement in the untreated 11-week-old KO animals, which was reversed by $1,25-\mathrm{D}_{3}$ treatment (Figure 2D). This was accompanied by a down-regulation of desmin and TRPC6 expression in the $1,25-\mathrm{D}_{3}$ supplemented mice compared with the 11-week-old KO to WT levels (Figure 2, E and F). Nephrin (Figure 2G) and podocin (Figure $2 \mathrm{H}$ ) expression levels were up-regulated to WT levels by $1,25-\mathrm{D}_{3}$ administration compared with the KO animals. No difference in the expression of the actin cytoskeleton scaffolding protein CD2AP was found (Figure 2I). The calcineurin/nuclear factor of activated 
A

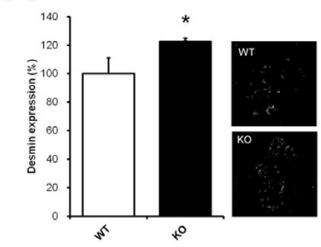

E
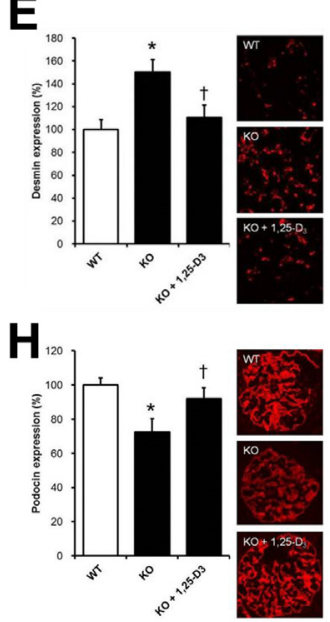

B

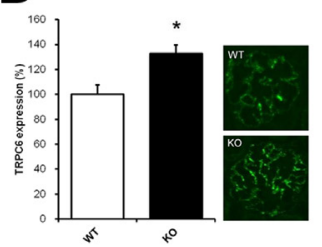

F
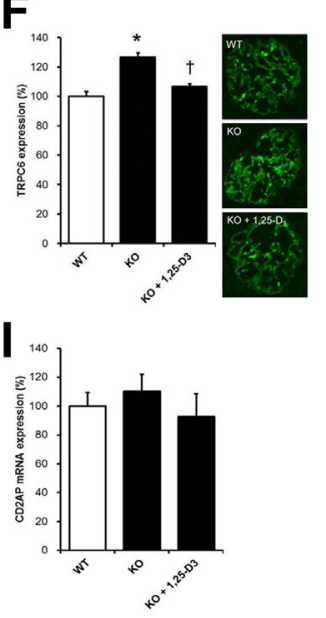

C

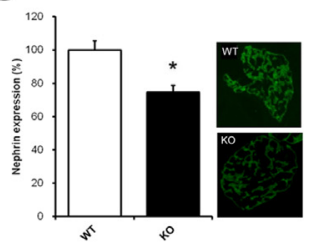

G
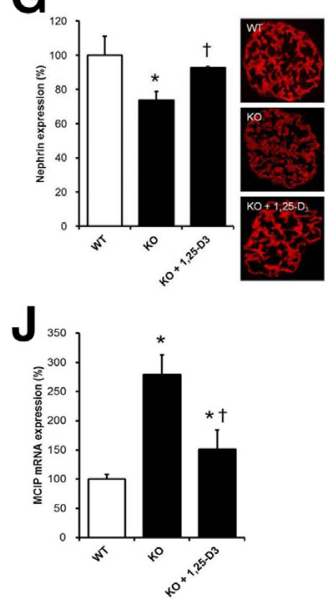

D

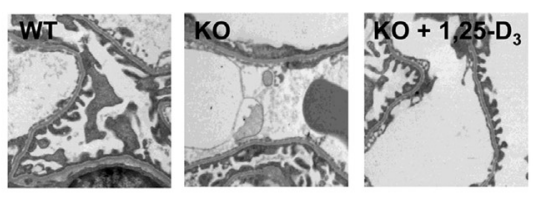

Figure 2 Podocyte injury and altered expression of key podocyte proteins in 25-hydroxy-vitamin- $D_{3}-1 \alpha$-hydroxylase knockout (1 $\alpha$ - 0 Hase $\left.\mathrm{K} 0\right)$ mice. Expression of podocyte damage markers desmin (A), transient receptor potential channel C6 (TRPC6; B), and nephrin (C) was determined in 4-week-old $1 \alpha-$ OHase KO and wild-type (WT) mice. Five-week-old $1 \alpha-0$ Hase K0 mice were given daily injections with a low dose $(25 \mathrm{pg} / \mathrm{g})$ of calcitriol $\left(1,25-\mathrm{D}_{3}\right)$ or vehicle for 6 weeks, after which mice were sacrificed. D: Renal ultrastructure was assessed by electron microscopy. Expression of desmin (E), TRPC6 (F), nephrin (G), podocin $(\mathbf{H}), \operatorname{CD} 2 A P(\mathbf{I})$, myocyte-enriched calcineurin-interacting protein (MCIP; J), and synaptopodin (K). Results are shown as percentage of vehicle-treated WT mice. Statistical tests used were $t$-test $(\mathbf{A}-\mathbf{C})$ and analysis of variance with Bonferroni post hoc analysis $(\mathbf{E}-\mathbf{K}) .{ }^{*} P<0.05$ versus WT; ${ }^{\dagger} P<0.05$ versus K0. $N=8$ mice per group $(\mathbf{A}-\mathbf{K})$. Original magnification, $\times 400 . \mathrm{K} 0$, knockout.

T-cell (NFAT) pathway was identified as a pathway enhancing podocyte injury. Next to TRPC6, myocyteenriched calcineurin-interacting protein is an NFAT target. ${ }^{32}$ Myocyte-enriched calcineurin-interacting protein expression was increased in $1 \alpha$-OHase $\mathrm{KO}$ mice and restored to WT levels when mice were supplemented with $1,25-\mathrm{D}_{3}$ (Figure $2 \mathrm{~J}$ ). Calcineurin activation might induce breakdown of the podocyte cytoskeletal protein synaptopodin. However, no significant differences in synaptopodin expression between groups were found (Figure 2K).

\section{GBM Composition Is Altered in $1,25-\mathrm{D}_{3}$ Deficiency}

EM analysis showed some variation in glomerular basement membrane (GBM) width in 11-week-old $1 \alpha$-OHase KO mice, where within one glomerular capillary loop thinner sections were present, reminiscent of GBM changes sometimes encountered in FSGS lesions (Supplemental Figure S1A). However, there was no clear global thinning or thickening, heterogeneity, or multiplication of the GBM. Interestingly, $1 \alpha$-OHase KO mice showed a mildly, but significantly, reduced glomerular collagen IV expression, which was no longer significant in the $1,25-\mathrm{D}_{3}$ supplementation group (Supplemental Figure S1B).

\section{Endocrine Alterations and Calcium-Phosphorus Balance in Inherited $1,25-D_{3}$ Deficiency}

Endocrine alterations secondary to $1,25-\mathrm{D}_{3}$ deficiency could be involved in the renal phenotype in these mice. Serum PTH level was significantly elevated in the $1 \alpha$-OHase $\mathrm{KO}$ mice, and remained high in the low-dosed vitamin D-supplemented mice (Table 2). No differences were observed in renal cortical PTH receptor expression. In contrast to PTH, serum levels of fibroblast growth factor 23 were not detectable in $\mathrm{KO}$ and vitamin D-supplemented KO mice. Renal VDR expression was strongly reduced in the $\mathrm{KO}$ mice, but was even lower in the $1,25-\mathrm{D}_{3}-$ supplemented $1 \alpha$-OHase $\mathrm{KO}$ group. The male and female $\mathrm{KO}$ mice had a decreased body weight and reduced serum calcium, albumin-corrected serum calcium, and serum phosphate compared with their WT littermates. The serum albumin levels were comparable between groups, suggesting that the significant proteinuria in $1 \alpha-\mathrm{OHase} \mathrm{KO}$ mice did not induce nephrotic syndrome. No difference was observed in blood urea nitrogen levels between groups.

\section{$1,25-D_{3}$ Deficiency Does Not Lead to Immune-Mediated Glomerular Injury}

Because vitamin D affects the immune system, immunemediated renal injury was examined. However, no differences 

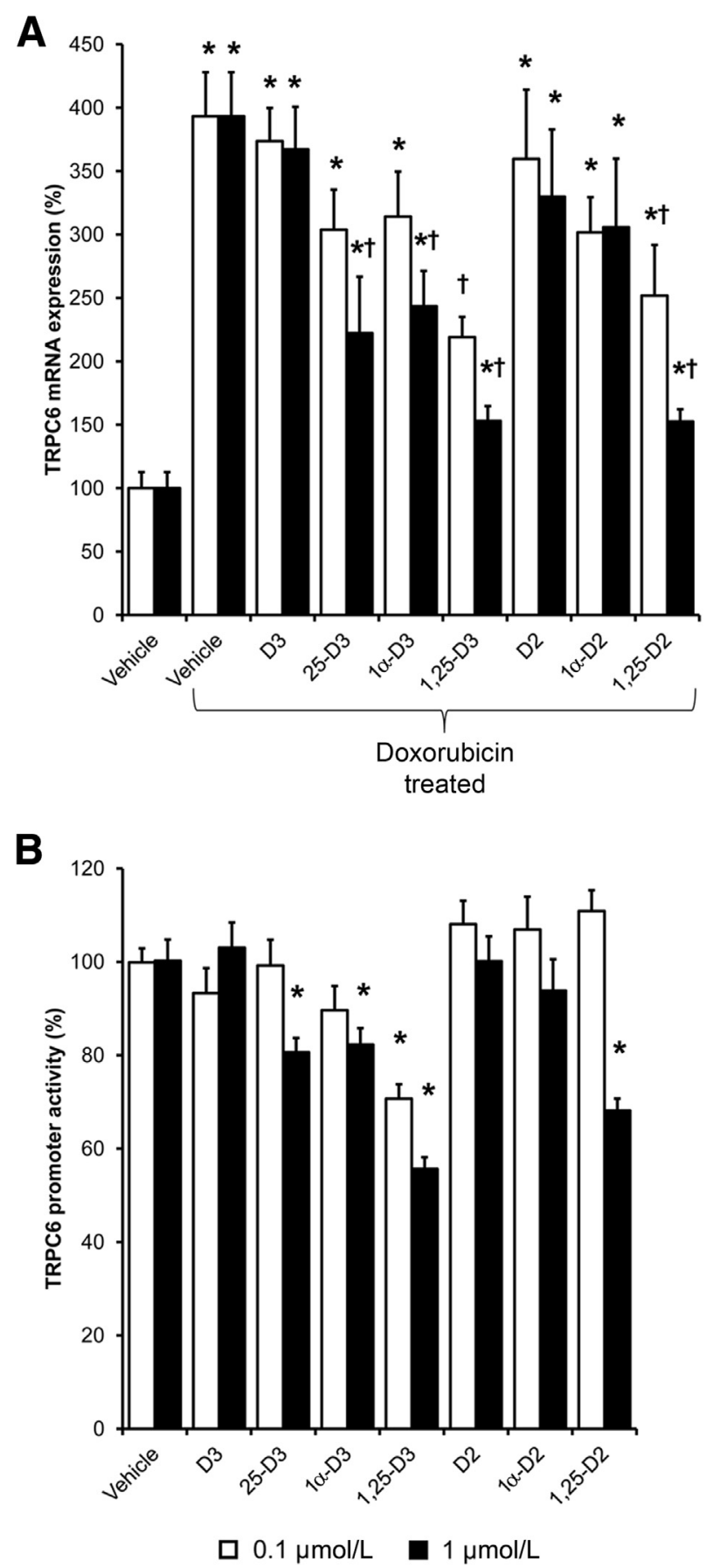

Figure 3 In vitro, calcitriol $\left(1,25-D_{3}\right)$ and paricalcitol $\left(1,25-D_{2}\right)$ downregulate the expression of the podocyte damage marker transient receptor potential channel C6 (TRPC6). A: Cultured podocytes were injured by doxorubicin (Adriamycin) application and treated with several vitamin $D$ analogs at a concentration of 0.1 and $1 \mu \mathrm{mol} / \mathrm{L}$, and TRPC 6 mRNA expression was measured. The effect of vitamin D analogs on TRPC6 promoter activity was examined using a luciferase promoter assay. Cells were treated with several vitamin $D$ analogs at a concentration of 0.1 and $1 \mu \mathrm{mol} / \mathrm{L}$. B: The Firefly/Renilla ratio was calculated and normalized for vehicle-treated cells. Each experiment was repeated at least twice. The statistical test used was analysis of variance with Bonferroni post hoc analysis (A and $\mathbf{B}) .{ }^{*} P<0.05$ versus vehicle-treated cells; ${ }^{\dagger} P<0.05$ versus vehicle-treated doxorubicin injured cells. $N=4$ to 8 podocyte cultures per group (A and B). $D_{2}$, ergocalciferol; $D_{3}$, cholecalciferol; $1 \alpha-D_{2}$, doxercalciferol; $1 \alpha-D_{3}, \alpha$-calcidiol; $25-D_{3}$, calcidiol. in IgG (Supplemental Figure S2A), IgA (Supplemental Figure S2B), IgM (Supplemental Figure S2C), or complement C3 (Supplemental Figure S2D) deposition were apparent. In addition, neither granulocyte influx (Supplemental Figure S2E), nor CD4 (Supplemental Figure S2F), CD8 (Supplemental Figure S2G), or CD68 (Supplemental Figure S2H) staining differed between treatment groups. Quantification of the staining described in this paragraph is shown in Supplemental Table S1.

\section{In Vitro $1,25-\mathrm{D}_{3}$ and $1,25-\mathrm{D}_{2}$ Down-Regulate Expression of Podocyte Damage Marker TRPC6}

Cultured MPC5 podocytes were injured using doxorubicin and treated with a wide range of vitamin D analogs, and podocyte injury was assessed by TRPC6 expression. We previously showed that the classic activated $1,25-\mathrm{D}_{3}$ analog down-regulates TRPC6 expression. ${ }^{26}$ Doxorubicin-injured podocytes showed increased TRPC6 expression when compared with control cells (Figure 3A). In doxorubicin-injured cells treated with 1,25- $\mathrm{D}_{3}$ and 19-nor-1,25-dihydroxyvitamin- $\mathrm{D}_{2}\left(1,25-\mathrm{D}_{2}\right)$ at a concentration of $100 \mathrm{nmol} / \mathrm{L}$, TRPC6 expression was down-regulated. At a concentration of $1.0 \mu \mathrm{mol} / \mathrm{L}$, all hydroxylated vitamin $\mathrm{D}_{3}$ analogs and $1,25-\mathrm{D}_{2}$ were able to down-regulate TRPC6 expression (Figure 3A). Moreover, we measured TRPC6 promoter activity using a luciferase TRPC6 promoter reporter construct. TRPC6 promoter activity showed a similar pattern when compared with the TRPC6 expression data, with the exception that treatment with $0.1 \mu \mathrm{mol} / \mathrm{L} 1,25-\mathrm{D}_{2} \mathrm{did}$ not result in a decreased TRPC6 promoter activity (Figure 3B).

\section{Both 1,25- $D_{3}$ and $1,25-D_{2}$ Supplementations Reverse Glomerular Injury in $1 \alpha-0$ Hase KO Mice}

Our in vitro data suggested that, in analogy to the classic role of vitamin $\mathrm{D}$ in mineral metabolism, the hydroxylation state of vitamin $\mathrm{D}$ analogs is also important for its protective effect in podocytes. Therefore, we treated $1 \alpha$-OHase $\mathrm{KO}$ mice with $1,25-\mathrm{D}_{3}$ and $1,25-\mathrm{D}_{2}$, which were in our in vitro experiments the most potent analogs down-regulating TRPC6 expression. We used a high-dose $1,25-\mathrm{D}_{3}$ and $1,25-\mathrm{D}_{2}$ that restored serum calcium to the WT level (WT, $2.24 \pm 0.04 \mathrm{mmol} / \mathrm{L}$; KO, $1.67 \pm 0.12 \mathrm{mmol} / \mathrm{L} ; \mathrm{KO}+1,25-\mathrm{D}_{2}, 2.18 \pm 0.13 \mathrm{mmol} / \mathrm{L}$; $\left.\mathrm{KO}+1,25-\mathrm{D}_{3}, 2.26 \pm 0.02 \mathrm{mmol} / \mathrm{L}\right)$. KO mice showed albuminuria (Figure 4A) and increased $\mathrm{IgG}$ excretion (Figure 4B), which were completely corrected by both vitamin $\mathrm{D}$ analogs. Moreover, tubulointerstitial damage was partly and completely reversed by $1,25-\mathrm{D}_{2}$ and $1,25-\mathrm{D}_{3}$, respectively (Figure 4C). EM showed that the partial podocyte foot process effacement in the KO mice was absent after treatment with both vitamin D analogs (Figure 4F). Expression of podocyte injury markers desmin and TRPC6 was increased in KO animals and normalized by $1,25-\mathrm{D}_{2}$ and $1,25-\mathrm{D}_{3}$ supplementation (Figure 4, D and E). More important, treating $1 \alpha$-OHase KO mice with a high $(2.0 \%)$ calcium diet versus a normal $(0.8 \%)$ calcium diet normalized serum calcium levels (WT, 



Figure 4 High-dose calcitriol $\left(1,25-D_{3}\right)$ and paricalcitol $\left(1,25-D_{2}\right)$ supplementation reverses glomerular injury in 25 -hydroxy-vitamin- $D_{3}-1 \alpha$-hydroxylase knockout $(1 \alpha-O H a s e ~ K 0)$ mice. Five-week-old $1 \alpha-0$ Hase $K 0$ mice were given daily i.p. injections with $1000 \mathrm{pg} / \mathrm{g} 1,25-\mathrm{D}_{2}$, a high-dose $1,25-\mathrm{D}_{3}(500 \mathrm{pg} / \mathrm{g})$, or vehicle for 6 weeks. Glomerular and tubulointerstitial injury was assessed by urinary albumin/creatinine ratio (A), IgG/creatinine ratio (B), and neutrophil gelatinase-associated lipocalin (NGAL) ratio (C). Expression of podocyte damage markers desmin (D) and transient receptor potential channel C6 (TRPC6; E). Five-week-old $1 \alpha-0$ Hase K0 mice received a $0.8 \%$ or $2.0 \%$ calcium diet for 6 weeks. F: Renal ultrastructure was assessed by electron microscopy. Glomerular and tubulointerstitial injury was assessed by urinary albumin/creatinine ratio $(\mathbf{G}), \operatorname{IgG}(\mathbf{H})$, and NGAL excretion $(\mathbf{I})$. Expression of podocyte damage markers desmin $(\mathbf{J})$ and TRPC6 protein $(\mathbf{K})$ was seen. Expression levels are depicted as percentage of vehicle-treated wild-type (WT) mice. Statistical tests used were analysis of variance with Bonferroni post hoc analysis (A-C, E, and $\mathbf{F}$ ) and $t$-test $(\mathbf{G}-\mathbf{K}) .{ }^{*} P<0.05$ versus $\mathrm{WT}^{\dagger}{ }^{\dagger} P<0.05$ versus $\mathrm{K} 0 . N=8$ mice per group $(\mathbf{A}-\mathbf{K})$. Original magnification, $\times 3000(\mathbf{F}) . \mathrm{K} 0, \mathrm{knockout}$.

$2.26 \pm 0.05 \mathrm{mmol} / \mathrm{L} ; \mathrm{KO}$ with $0.8 \%$ calcium diet, $1.61 \pm 0.10$ $\mathrm{mmol} / \mathrm{L}$; KO with $2.0 \%$ calcium diet, $2.21 \pm 0.09 \mathrm{mmol} / \mathrm{L}$ ), but did not reverse renal injury in $1 \alpha$-OHase KO mice, as shown by albumin/creatinine ratio (Figure $4 \mathrm{G}$ ), urinary $\operatorname{IgG}$ (Figure 4H), and NGAL (Figure 4I) excretion. Moreover, glomerular desmin (Figure 4J) and TRPC6 (Figure 4K) expression did not differ between diets. Accordingly, the normocalcemic $1 \alpha$-OHase $\mathrm{KO}$ on a high calcium diet still showed partial podocyte foot process effacement (Figure 4F), to a comparable extent as the untreated hypocalcemic $\mathrm{KO}$ mice.

Acquired $1,25-D_{3}$ Deficiency Also Leads to Glomerular and Tubulointerstitial Injury and Proteinuria

In addition to genetic $1,25-\mathrm{D}_{3}$ deficiency, we also studied acquired $1,25-\mathrm{D}_{3}$ deficiency in rats. After depleting the endogenous vitamin $\mathrm{D}$ pool, $1,25-\mathrm{D}_{3}$ serum levels were lower compared with control animals (control, $295 \pm 58 \mathrm{pmol} / \mathrm{L}$; deficient, $35 \pm 9 \mathrm{pmol} / \mathrm{L}$; $P<0.05)$, thus rendering these animals 1,25 -vitamin $\mathrm{D}_{3}$ deficient. After 5 weeks, a significant albuminuria (Figure 5A) and increased urinary $\mathrm{IgG}$ excretion (Figure 5B) were observed, which could be prevented by supplementation with $1,25-\mathrm{D}_{2}$ and $1,25-\mathrm{D}_{3}$. Urinary NGAL excretion was also increased in the 1,25-vitamin $\mathrm{D}_{3}$-deficient animals and reduced with $1,25-\mathrm{D}_{2}$ and $1,25-\mathrm{D}_{3}$ supplementation (Figure $5 \mathrm{C}$ ). EM revealed no ultrastructural alterations (results not shown). However, the expression of desmin (Figure 5D) and TRPC6 (Figure 5E) was up-regulated in vitamin $\mathrm{D}$-deficient rats compared with either control or $1,25-\mathrm{D}_{2}$ and $1,25-\mathrm{D}_{3}$ supplemented groups. 

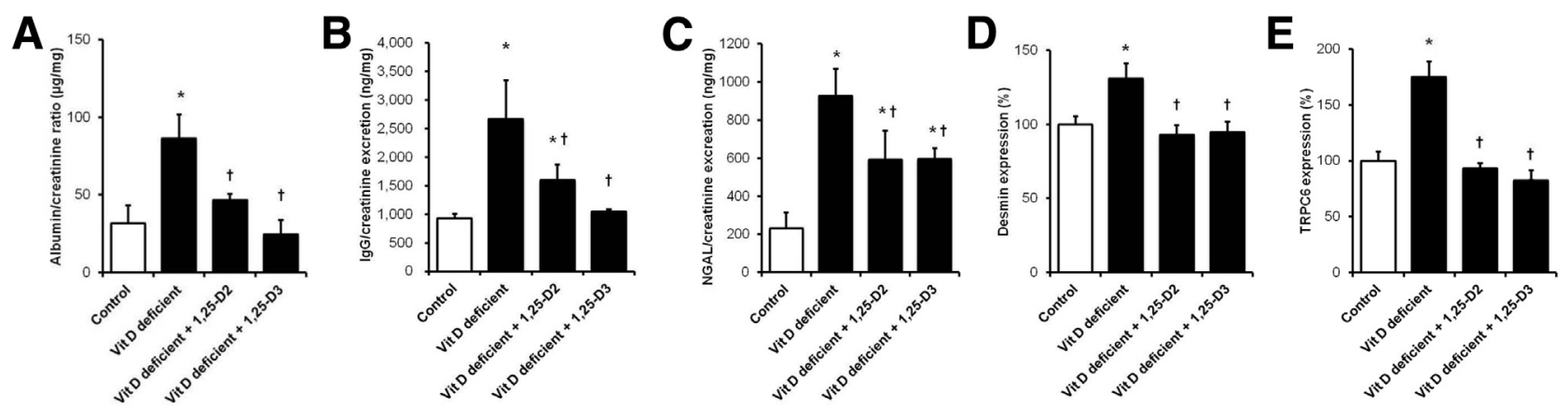

Figure 5 Acquired 1,25-vitamin (Vit) $D_{3}$ deficiency leads to glomerular and tubulointerstitial injury and proteinuria. Wistar rats were made vitamin $D$ deficient and, subsequently, treated with paricalcitol $\left(1,25-\mathrm{D}_{2}\right)$ or calcitriol $\left(1,25-\mathrm{D}_{3}\right)$ for 5 weeks. Glomerular and tubulointerstitial injury was assessed by urinary albumin/creatinine ratio (A), IgG/creatinine ratio (B), and neutrophil gelatinase-associated lipocalin (NGAL)/creatinine ratio excretion (C). Expression of podocyte damage markers desmin (D) and transient receptor potential channel C6 (TRPC6; E). Protein and mRNA expression levels are depicted as percentage of control. The statistical test used was analysis of variance with Bonferroni post hoc analysis. ${ }^{*} P<0.05$ versus control; ${ }^{\dagger} P<0.05$ versus untreated rats. $N=8$ rats per group $(\mathbf{A}-\mathbf{E})$.

\section{Endocrine Alterations and Calcium-Phosphorus Balance in Acquired $1,25-D_{3}$ Deficiency}

Endocrine alterations secondary to $1,25-\mathrm{D}_{3}$ deficiency could be involved in the renal phenotype in these rats. Serum PTH levels were significantly elevated in the $1,25-\mathrm{D}_{3}$-deficient rats, as well as in the vitamin D-supplemented rats (Table 3). No difference was observed in body weight, serum calcium, and corrected serum calcium. A high phosphorus diet caused serum phosphate to be elevated in the deficient groups. No differences were observed in serum albumin and blood urea nitrogen levels between groups.

\section{Discussion}

The present study demonstrated that hereditary and acquired 1,25 -vitamin $\mathrm{D}_{3}$ deficiency leads to $1,25-\mathrm{D}_{3}-$ and 1,25 $\mathrm{D}_{2}-$ remediable glomerular injury and albuminuria, as well as tubulointerstitial damage in $1,25-\mathrm{D}_{3}$ deficient $1 \alpha$-OHase KO mice. Moreover, KO mice showed partial podocyte foot process effacement, altered expression of functionally relevant slit-diaphragm-associated proteins, and activation of the deleterious calcineurin/NFAT pathway. Acquired 1,25$\mathrm{D}_{3}$ deficiency in rats also induced proteinuria, in combination with an increased expression of podocyte injury markers. In vitro, we determined that the fully hydroxylated $1,25-\mathrm{D}_{3}$ and $1,25-\mathrm{D}_{2}$ analogs were most potent in preventing the up-regulation of the podocyte injury marker TRPC6. In vivo, $1,25-\mathrm{D}_{3}$ and $1,25-\mathrm{D}_{2}$ supplementation largely reversed glomerular injury and the above described expressional changes. Thus, this study provides important evidence that vitamin $\mathrm{D}$ treatment is not only able to ameliorate, but also to reverse, podocyte injury, at least in $1,25-\mathrm{D}_{3}$-deficient animal models. Reversal of podocyte injury would be consistent with the debated antiproteinuric effect of vitamin D analogs in clinical practice.

Herein, we showed that loss of 25-hydroxy-vitamin- $\mathrm{D}_{3}$ $1 \alpha$-hydroxylation capacity, which also occurs in patients with renal insufficiency, and acquired $1,25-\mathrm{D}_{3}$ deficiency lead to renal injury. An association between low 25hydroxyvitamin D levels and an increased prevalence of albuminuria was previously described in a population-based survey. ${ }^{13}$ A causal relationship between both could not be proved. However, vitamin D analogs have been suggested to ameliorate proteinuria in several glomerular diseases. ${ }^{9-11}$

Table 3 Clinical Parameters in Acquired $1,25-D_{3}$ Deficiency and Vitamin D Supplementation in Rats

\begin{tabular}{lcccc}
\hline Parameters & Control & $1,25-D_{3}$ deficiency & $1,25-D_{3}$ deficiency $+1,25-D_{2}$ & $1,25-D_{3}$ deficiency $+1,25-D_{3}$ \\
\hline Serum PTH (pg/mL) & $29 \pm 12$ & $56 \pm 14^{*}$ & $18 \pm 2^{* \dagger}$ & $28 \pm 7^{\dagger}$ \\
Body weight (g) & $463 \pm 23$ & $445 \pm 30$ & $446 \pm 29$ & $447 \pm 34$ \\
Serum calcium (mmol/L) & $3.29 \pm 0.03$ & $3.30 \pm 0.07$ & $3.36 \pm 0.05$ & $3.34 \pm 0.05$ \\
Corrected serum calcium (mmol/L) & $3.7 \pm 0.03$ & $3.7 \pm 0.09$ & $3.7 \pm 0.07$ & $3.7 \pm 0.11$ \\
Serum phosphate (mmol/L) & $2.51 \pm 0.18$ & $3.34 \pm 0.37^{*}$ & $3.37 \pm 0.28^{*}$ & $3.98 \pm 0.42^{*}$ \\
Serum albumin (g/L) & $22.1 \pm 2.1$ & $21.6 \pm 1.4$ & $21.2 \pm 2.4$ & $23.8 \pm 2.2$ \\
Blood urea nitrogen (mg/dL) & $28.8 \pm 3.8$ & $30.1 \pm 2.1$ & $29.6 \pm 6.0$ & $28.9 \pm 3.9$ \\
\hline
\end{tabular}

Vitamin D-deficient rats were treated with $1,25-D_{2}, 1,25-D_{3}$, or vehicle. Deficient rats were treated with a high calcium and phosphate diet. The weight of the rats was determined, and blood samples were analyzed. Data are given as means $\pm \mathrm{SD}$.

${ }^{*} P<0.05$ vs control.

${ }^{\dagger} P<0.05$ vs $1,25-D_{3}-$ deficient rats.

PTH, parathyroid hormone; $1,25-\mathrm{D}_{2}$, paricalcitol; $1,25-\mathrm{D}_{3}$, calcitriol. 
In the present study, two models for vitamin D deficiency in two different species were used to show that $1,25-\mathrm{D}_{3}$ deficiency results in podocyte injury and glomerular proteinuria.

Although overt podocyte effacement was not yet present in 4-week-old $1 \alpha$-OHase KO mice, proteinuria and glomerular injury markers were already detectable. Moreover, a significant progressive urinary albumin loss was found when 4- and 11-week-old 1,25- $\mathrm{D}_{3}$-deficient $\mathrm{KO}$ mice are compared, the latter showing clear podocyte effacement. Interestingly, the urine $\mathrm{IgG}$ excretion is reduced after 4 weeks, which could be a consequence of weaning of the mice. $\operatorname{IgG}$ is transferred to offspring via the milk. Thus, after weaning, this $\operatorname{IgG}$ source is lost, which is probably reflected by the decreased $\operatorname{IgG}$ urine excretion in the presence of persistent glomerular injury. Previously, it was shown that the VDR is expressed in the glomerulus, especially in podocytes and parietal epithelial cells. ${ }^{22}$ The renoprotective effects of vitamin D might thus be mediated locally by directly affecting the podocyte, or theoretically other glomerular cells, like the glomerular endothelium, with which there is considerable cross talk. However, because vitamin $\mathrm{D}$ is a pluripotent hormone, also acting on hematopoietic cells, we cannot completely exclude that the effects found in this study are indirectly regulated through effects on other cell types or tissues. ${ }^{33}$

In both the inherited and the acquired vitamin Ddeficient models, we demonstrated down-regulation of the expression of structural slit diaphragm-associated proteins nephrin and podocin and up-regulation of TRPC6 expression. In proteinuric glomerular diseases, such as acquired FSGS, membranous nephropathy, and diabetic nephropathy, decreased expression of podocin and nephrin and TRPC6 overexpression were reported. ${ }^{34-36}$ Loss-of-function mutations in nephrin and podocin, as well as TRPC6 gain-of-function mutations, lead to (congenital) nephrotic syndrome and hereditary FSGS. ${ }^{37-40}$ Previous studies already suggested that vitamin D regulates nephrin and podocin expression. ${ }^{24,25}$ In accordance, diabetic VDR KO mice and rats that constitutively express CYP24A1, the enzyme breaking down $1,25-\mathrm{D}_{3}$, displayed proteinuria accompanied by podocyte effacement and decreased nephrin expression. ${ }^{41,42}$ More important, healthy VDR KO and animals overexpressing CYP24A1 also experienced increased urinary protein loss. Wang et $\mathrm{al}^{25}$ demonstrated that overexpression of the VDR in podocytes protects the kidney from diabetic injury. We previously demonstrated that $1,25-\mathrm{D}_{3}$ specifically binds to the TRPC6 promoter region, thereby down-regulating TRPC6 expression. ${ }^{26}$ The combination of podocin expressional loss and TRPC6 up-regulation in $1,25-\mathrm{D}_{3}$-deficient animals is particularly significant because podocin regulates TRPC6 channel gating in podocytes. It was recently demonstrated that podocin knockdown markedly increases TRPC6 mechanosensitivity and would lead to a profound TRPC6 overactivation in podocyte foot processes, leading to a situation of $\mathrm{Ca}^{2+}$ overload. ${ }^{43}$ In addition, the channel appears to function in a deleterious angiotensin II-induced positive feedback TRPC6-calcineurin/NFAT-TRPC6 signaling loop in the podocyte, which might be enhanced by $1,25-\mathrm{D}_{3}$ deficiency. ${ }^{12,31}$ Myocyte-enriched calcineurin-interacting protein expression, as a measure of calcineurin/NFAT activity, was increased in kidneys of $1 \alpha$-OHase $\mathrm{KO}$ animals. Calcineurin activation was also shown to lead to dephosphorylation of the podocyte-specific actin-binding protein synaptopodin, which is crucial for maintaining the podocyte actin cytoskeleton. ${ }^{44,45}$ However, enhanced synaptopodin degradation does not appear to have occurred in these mice. Although an attractive hypothesis, the proof for TRPC6-activated and subsequent calcineurin-mediated synaptopodin degradation has yet to be delivered. $1,25-\mathrm{D}_{3}$ deficiency in the $\mathrm{KO}$ mice also increased tubulointerstitial damage, as exemplified by detection of increased NGAL as a tubular injury marker and caspase-3 as a measure of apoptotic tubular cells. Although a low dose of vitamin $\mathrm{D}$ did not alter urinary NGAL excretion, a higher dose of $1,25-\mathrm{D}_{3}$ normalized NGAL excretion, which was also partially accomplished by $1,25-\mathrm{D}_{2}$. In contrast to NGAL, cleaved caspase 3 expression was already decreased by a low dose of vitamin $D$, indicating fewer apoptotic cells. Whether the GBM alterations and interstitial injury are a direct result of $1,25-\mathrm{D}_{3}$ deficiency, or are secondary to the proteinuria, is not evident from our data. Because most GBM constituents are produced by the podocytes, podocyte injury could be suggested to affect the GBM. Consistent with our results, VDR KO mice showed increased tubular atrophy and interstitial fibrosis when subjected to unilateral urethral obstruction. ${ }^{46}$ Inoue et $\mathrm{al}^{47}$ found that the vitamin $\mathrm{D}$ analog maxacalcitol prevented tubulointerstitial fibrosis in urethral obstructed rats. A beneficial effect of vitamin $\mathrm{D}$ on caspase 3 expression was shown in several renal injury models. ${ }^{11,48}$ The reversal of the interstitial damage in our study by $1,25-\mathrm{D}_{3}$ might need higher vitamin $\mathrm{D}$ supplementation doses, or more time to recover when it is secondary to the glomerular injury.

Taken together, regulation of nephrin, podocin, and TRPC6 expression by $1,25-\mathrm{D}_{3}$ in inherited and acquired $1,25-\mathrm{D}_{3}$ deficiency appears to be involved in the glomerular injury and proteinuria in $1,25-\mathrm{D}_{3}-$ deficient animals. The reversal of these effects by $1,25-\mathrm{D}_{2}$ and $1,25-\mathrm{D}_{3}$ treatment demonstrated that vitamin $\mathrm{D}$ can reverse podocyte injury and prevent foot process effacement, and that the phenotype is vitamin D dependent. An important additional mediator that could be partly responsible for the described effects is the renin-angiotensin system, which is regulated by $1,25-\mathrm{D}_{3}$. It was previously shown that administration of $1,25-\mathrm{D}_{3}$ reduces blood pressure, plasma renin activity, and angiotensin II levels. Consistent with this, $1 \alpha$-OHase KO mice have a $1,25-\mathrm{D}_{3}-$ dependent increased blood pressure, renin, and angiotensin II level, and particularly the latter is known to be an important pathogenic factor in glomerular injury. ${ }^{49}$ However, as outlined, the direct transcriptional regulation of nephrin, podocin, and TRPC6 was previously demonstrated. ${ }^{23-27}$ Hypothetically, the calcium/ phosphate homeostasis, or the hormonal regulation thereof, could be mediating the deleterious effect of $1,25-\mathrm{D}_{3}$ deficiency. However, we could not demonstrate sustained correlation between the proteinuric phenotype in both animal 
models and serum levels of fibroblast growth factor 23, PTH, phosphate, and calcium. More important, $\mathrm{Ca}^{2+}$ supplementation itself, normalizing serum calcium, did not correct the phenotype. To further study the contribution of possible mechanistic contributors, the generation of kidney- or even podocyte-specific $1 \alpha$-OHase KO mice would represent valuable tools for future research.

In conclusion, we demonstrated that $1,25-\mathrm{D}_{3}$ deficiency leads to glomerular and tubulointerstitial damage. When translated to human subjects, this has clear implications for clinical practice. Patients with glomerular diseases and/or proteinuria should be tested for $\left(1,25\right.$-)vitamin $\mathrm{D}_{3}$ deficiency, and supplementation of $1,25-\mathrm{D}_{3}$ or $1,25-\mathrm{D}_{2}$ should be considered. Furthermore, our data add mechanistic evidence to the debate on the antiproteinuric and renoprotective effects of vitamin D, suggesting that vitamin D supplementation might be indicated in patients with renal function decline in an earlier phase, before the development of overt hyperparathyroidism. However, this strategy would have to be based on solid clinical trials showing that early vitamin D treatment reduces the rate of renal function decline in human patients, which are not available in the literature as yet. In general, these data provide new input into the debate on the pluripotent effects of vitamin $\mathrm{D}$, at a moment when the initial excitement seems to be fading.

\section{Acknowledgments}

We thank Dr. Rene St. Arnaud (McGill University, Montreal, Quebec, Canada) for kindly providing the 25-hydroxy-1 $\alpha$ hydroxylase knockout mouse model, Dr. Jochen Reiser (Rush University, Chicago, IL) for providing the MPC-5 mouse podocyte cell line, Drs. Piet ter Wee and Robert Beelen for their supervision of A.S. and E.F, and AbbVie (Chicago, IL) for the generous gift of paricalcitol (Zemplar).

\section{Supplemental Data}

Supplemental material for this article can be found at http://dx.doi.org/10.1016/j.ajpath.2015.11.015.

\section{References}

1. Battault S, Whiting SJ, Peltier SL, Sadrin S, Gerber G, Maixent JM: Vitamin D metabolism, functions and needs: from science to health claims. Eur J Nutr 2012, 52:429-441

2. Leffelaar ER, Vrijkotte TG, van Eijsden M: Maternal early pregnancy vitamin D status in relation to fetal and neonatal growth: results of the multi-ethnic Amsterdam Born Children and their Development cohort. Br J Nutr 2010, 104:108-117

3. Parfitt AM, Mathews CH, Brommage R, Jarnagin K, DeLuca HF: Calcitriol but no other metabolite of vitamin D is essential for normal bone growth and development in the rat. J Clin Invest 1984, 73: $576-586$

4. Autier P, Gandini S: Vitamin D supplementation and total mortality: a meta-analysis of randomized controlled trials. Arch Intern Med 2007, $167: 1730-1737$
5. Skaaby T, Husemoen LL, Pisinger C, Jorgensen T, Thuesen BH, Fenger M, Linneberg A: Vitamin D status and incident cardiovascular disease and all-cause mortality: a general population study. Endocrine 2013, 43:618-625

6. Cheung FS, Lovicu FJ, Reichardt JK: Current progress in using vitamin D and its analogs for cancer prevention and treatment. Expert Rev Anticancer Ther 2012, 12:811-837

7. Fleet JC, DeSmet M, Johnson R, Li Y: Vitamin D and cancer: a review of molecular mechanisms. Biochem J 2012, 441:61-76

8. White JH: Regulation of intracrine production of 1,25 dihydroxyvitamin $\mathrm{D}$ and its role in innate immune defense against infection. Arch Biochem Biophys 2012, 523:58-63

9. Cheng J, Zhang W, Zhang X, Li X, Chen J: Efficacy and safety of paricalcitol therapy for chronic kidney disease: a meta-analysis. Clin J Am Soc Nephrol 2012, 7:391-400

10. Kuhlmann A, Haas CS, Gross ML, Reulbach U, Holzinger M, Schwarz U, Ritz E, Amann K: 1,25-Dihydroxyvitamin D3 decreases podocyte loss and podocyte hypertrophy in the subtotally nephrectomized rat. Am J Physiol Renal Physiol 2004, 286: F526-F533

11. Zou MS, Yu J, Nie GM, He WS, Luo LM, Xu HT: 1, 25Dihydroxyvitamin D3 decreases adriamycin-induced podocyte apoptosis and loss. Int J Med Sci 2010, 7:290-299

12. de Borst MH, Vervloet MG, ter Wee PM, Navis G: Cross talk between the renin-angiotensin-aldosterone system and vitamin D-FGF-23klotho in chronic kidney disease. J Am Soc Nephrol 2011, 22: $1603-1609$

13. de Boer IH, Ioannou GN, Kestenbaum B, Brunzell JD, Weiss NS: 25Hydroxyvitamin D levels and albuminuria in the Third National Health and Nutrition Examination Survey (NHANES III). Am J Kidney Dis 2007, 50:69-77

14. Chowdhury R, Kunutsor S, Vitezova A, Oliver-Williams C, Chowdhury S, Kiefte-de-Jong JC, Khan H, Baena CP, Prabhakaran D, Hoshen MB, Feldman BS, Pan A, Johnson L, Crowe F, Hu FB, Franco OH: Vitamin D and risk of cause specific death: systematic review and meta-analysis of observational cohort and randomised intervention studies. BMJ 2014, 348:g1903

15. Keyzer CA, Lambers-Heerspink HJ, Joosten MM, Deetman PE, Gansevoort RT, Navis G, Kema IP, de Zeeuw D, Bakker SJ, de Borst MH, Group PS: Plasma vitamin D level and change in albuminuria and eGFR according to sodium intake. Clin J Am Soc Nephrol 2015, 10:2119-2127

16. Durvasula RV, Petermann AT, Hiromura K, Blonski M, Pippin J, Mundel P, Pichler R, Griffin S, Couser WG, Shankland SJ: Activation of a local tissue angiotensin system in podocytes by mechanical strain. Kidney Int 2004, 65:30-39

17. Endlich N, Kress KR, Reiser J, Uttenweiler D, Kriz W, Mundel P, Endlich K: Podocytes respond to mechanical stress in vitro. J Am Soc Nephrol 2001, 12:413-422

18. Kaplan JM, Kim SH, North KN, Rennke H, Correia LA, Tong HQ, Mathis BJ, Rodriguez-Perez JC, Allen PG, Beggs AH, Pollak MR: Mutations in ACTN4, encoding alpha-actinin-4, cause familial focal segmental glomerulosclerosis. Nat Genet 2000, 24:251-256

19. White KE, Bilous RW: Structural alterations to the podocyte are related to proteinuria in type 2 diabetic patients. Nephrol Dial Transplant 2004, 19:1437-1440

20. Levin A, Bakris GL, Molitch M, Smulders M, Tian J, Williams LA, Andress DL: Prevalence of abnormal serum vitamin D, PTH, calcium, and phosphorus in patients with chronic kidney disease: results of the study to evaluate early kidney disease. Kidney Int 2007, 71:31-38

21. Stumpf WE, Sar M, Narbaitz R, Reid FA, DeLuca HF, Tanaka Y: Cellular and subcellular localization of 1,25-(OH)2-vitamin D3 in rat kidney: comparison with localization of parathyroid hormone and estradiol. Proc Natl Acad Sci U S A 1980, 77:1149-1153

22. Wang Y, Borchert ML, Deluca HF: Identification of the vitamin D receptor in various cells of the mouse kidney. Kidney Int 2012, 81: 993-1001 
23. Deb DK, Wang Y, Zhang Z, Nie H, Huang X, Yuan Z, Chen Y, Zhao Q, Li YC: Molecular mechanism underlying 1,25dihydroxyvitamin $\mathrm{D}$ regulation of nephrin gene expression. J Biol Chem 2011, 286:32011-32017

24. Zou MS, Yu J, Zhou JH, Nie GM, Ding DS, Luo LM, Xu HT, He WS: 1,25-Dihydroxyvitamin D3 ameliorates podocytopenia in rats with adriamycin-induced nephropathy. Intern Med 2010, 49:2677-2686

25. Wang Y, Deb DK, Zhang Z, Sun T, Liu W, Yoon D, Kong J, Chen Y, Chang A, Li YC: Vitamin D receptor signaling in podocytes protects against diabetic nephropathy. J Am Soc Nephrol 2012, 23:1977-1986

26. Sonneveld R, Ferrè S, Hoenderop JGJ, Dijkman HB, Berden JHM, Bindels RJM, Wetzels JFM, Vlag J, Nijenhuis T: Vitamin D downregulates TRPC6 expression in podocyte injury and proteinuric glomerular disease. Am J Pathol 2013, 182:1196-1204

27. Dardenne O, Prud'homme J, Arabian A, Glorieux FH, St-Arnaud R: Targeted inactivation of the 25-hydroxyvitamin D(3)-1(alpha)hydroxylase gene (CYP27B1) creates an animal model of pseudovitamin D-deficiency rickets. Endocrinology 2001, 142:3135-3141

28. Hoenderop JG, Dardenne O, Van Abel M, Van Der Kemp AW, Van Os CH, St-Arnaud R, Bindels RJ: Modulation of renal Ca2+ transport protein genes by dietary $\mathrm{Ca} 2+$ and 1,25-dihydroxyvitamin D3 in 25hydroxyvitamin D3-1alpha-hydroxylase knockout mice. FASEB J 2002, 16:1398-1406

29. Stavenuiter AWD, Arcidiacono MV, Ferrantelli E, Keuning ED, Cuenca MV: A novel rat model of vitamin D deficiency: safe and rapid induction of vitamin D and calcitriol deficiency without hyperparathyroidism. Biomed Res Int 2015, 2015:5

30. Mundel P, Reiser J, Zuniga Mejia Borja A, Pavenstadt H, Davidson GR, Kriz W, Zeller R: Rearrangements of the cytoskeleton and cell contacts induce process formation during differentiation of conditionally immortalized mouse podocyte cell lines. Exp Cell Res 1997, 236:248-258

31. Nijenhuis T, Sloan AJ, Hoenderop JG, Flesche J, van Goor H, Kistler AD, Bakker M, Bindels RJ, de Boer RA, Moller CC, Hamming I, Navis G, Wetzels JF, Berden JH, Reiser J, Faul C, van der Vlag J: Angiotensin II contributes to podocyte injury by increasing TRPC6 expression via an NFAT-mediated positive feedback signaling pathway. Am J Pathol 2011, 179:1719-1732

32. Shin SY, Yang JM, Choo SM, Kwon KS, Cho KH: System-level investigation into the regulatory mechanism of the calcineurin/NFAT signaling pathway. Cell Signal 2008, 20:1117-1124

33. Carlberg C, Seuter S, Heikkinen S: The first genome-wide view of vitamin D receptor locations and their mechanistic implications. Anticancer Res 2012, 32:271-282

34. Jim B, Ghanta M, Qipo A, Fan Y, Chuang PY, Cohen HW, Abadi M, Thomas DB, He JC: Dysregulated nephrin in diabetic nephropathy of type 2 diabetes: a cross sectional study. PLoS One 2012, 7:e36041

35. Nakatsue T, Koike H, Han GD, Suzuki K, Miyauchi N, Yuan H, Salant DJ, Gejyo F, Shimizu F, Kawachi H: Nephrin and podocin dissociate at the onset of proteinuria in experimental membranous nephropathy. Kidney Int 2005, 67:2239-2253

36. Doublier S, Ruotsalainen V, Salvidio G, Lupia E, Biancone L, Conaldi PG, Reponen P, Tryggvason K, Camussi G: Nephrin redistribution on podocytes is a potential mechanism for proteinuria in patients with primary acquired nephrotic syndrome. Am J Pathol 2001, 158:1723-1731
37. Kestila M, Lenkkeri U, Mannikko M, Lamerdin J, McCready P, Putaala H, Ruotsalainen V, Morita T, Nissinen M, Herva R, Kashtan CE, Peltonen L, Holmberg C, Olsen A, Tryggvason K: Positionally cloned gene for a novel glomerular protein-nephrin-is mutated in congenital nephrotic syndrome. Mol Cell 1998, 1: $575-582$

38. Boute N, Gribouval O, Roselli S, Benessy F, Lee H, Fuchshuber A, Dahan K, Gubler MC, Niaudet P, Antignac C: NPHS2, encoding the glomerular protein podocin, is mutated in autosomal recessive steroidresistant nephrotic syndrome. Nat Genet 2000, 24:349-354

39. Reiser J, Polu KR, Moller CC, Kenlan P, Altintas MM, Wei C, Faul C, Herbert S, Villegas I, Avila-Casado C, McGee M, Sugimoto H, Brown D, Kalluri R, Mundel P, Smith PL, Clapham DE, Pollak MR: TRPC6 is a glomerular slit diaphragm-associated channel required for normal renal function. Nat Genet 2005, 37:739-744

40. Winn MP, Conlon PJ, Lynn KL, Farrington MK, Creazzo T, Hawkins AF, Daskalakis N, Kwan SY, Ebersviller S, Burchette JL, Pericak-Vance MA, Howell DN, Vance JM, Rosenberg PB: A mutation in the TRPC6 cation channel causes familial focal segmental glomerulosclerosis. Science 2005, 308:1801-1804

41. Kasuga H, Hosogane N, Matsuoka K, Mori I, Sakura Y, Shimakawa K, Shinki T, Suda T, Taketomi S: Characterization of transgenic rats constitutively expressing vitamin D-24-hydroxylase gene. Biochem Biophys Res Commun 2002, 297:1332-1338

42. Zhang Z, Sun L, Wang Y, Ning G, Minto AW, Kong J, Quigg RJ, Li YC: Renoprotective role of the vitamin D receptor in diabetic nephropathy. Kidney Int 2008, 73:163-171

43. Anderson M, Kim EY, Hagmann H, Benzing T, Dryer SE: Opposing effects of podocin on the gating of podocyte TRPC6 channels evoked by membrane stretch or diacylglycerol. Am J Physiol Cell Physiol 2013, 305:C276-C289

44. Faul C, Donnelly M, Merscher-Gomez S, Chang YH, Franz S, Delfgaauw J, Chang JM, Choi HY, Campbell KN, Kim K, Reiser J, Mundel P: The actin cytoskeleton of kidney podocytes is a direct target of the antiproteinuric effect of cyclosporine A. Nat Med 2008, 14: 931-938

45. Asanuma K, Kim K, Oh J, Giardino L, Chabanis S, Faul C, Reiser J, Mundel P: Synaptopodin regulates the actin-bundling activity of alphaactinin in an isoform-specific manner. J Clin Invest 2005, 115: $1188-1198$

46. Zhang Y, Kong J, Deb DK, Chang A, Li YC: Vitamin D receptor attenuates renal fibrosis by suppressing the renin-angiotensin system. J Am Soc Nephrol 2010, 21:966-973

47. Inoue K, Matsui I, Hamano T, Fujii N, Shimomura A, Nakano C, Kusunoki Y, Takabatake Y, Hirata M, Nishiyama A, Tsubakihara Y, Isaka Y, Rakugi H: Maxacalcitol ameliorates tubulointerstitial fibrosis in obstructed kidneys by recruiting PPM1A/VDR complex to pSmad3. Lab Invest 2012, 92:1686-1697

48. Piao SG, Song JC, Lim SW, Chung BH, Choi BS, Yang CW: Protective effect of paricalcitol on cyclosporine-induced renal injury in rats. Transplant Proc 2012, 44:642-645

49. Zhou C, Lu F, Cao K, Xu D, Goltzman D, Miao D: Calcium-independent and 1,25(OH)2D3-dependent regulation of the reninangiotensin system in 1alpha-hydroxylase knockout mice. Kidney Int 2008, 74:170-179 